\title{
Colored shade nets induced changes in growth, anatomy and essential oil of Pogostemon cablin
}

\author{
AURISLAINE S. RIBEIRO, MARIANA S. RIBEIRO, SUZAN K.V. BERTOLUCCI, \\ WANDERLEY J.M. BITTENCOURT, ALEXANDRE A. DE CARVALHO, \\ WESLEY N. TOSTES, EDUARDO ALVES and JOSÉ E.B.P. PINTO \\ ${ }^{1}$ Laboratório de Cultura de Tecidos e Plantas Medicinais, Departamento de Agricultura, Universidade \\ Federal de Lavras, Campus Universitário, Caixa Postal 3037, 37200-000 Lavras, MG, Brazil
}

Manuscript received on April 28, 2017; accepted for publication on December 20, 2017

\begin{abstract}
The purpose of this investigation was to determine the influence of colored shade nets on the growth, anatomy and essential oil content, yield and chemical composition of Pogostemon cablin. The plants were cultivated under full sunlight, black, blue and red nets. The harvesting was performed 5 months after planting and it was followed by the analysis of plant growth parameters, leaf anatomy, essential oil content, yield and chemical composition. The plants grown under red net have produced more leaf, shoot, total dry weight and leaf area. Plants cultivated under colored nets showed differences in morphological features. Plants maintained under red net had a higher leaf blade thickness and polar and equatorial diameter of the stomata ratio. Additionally, higher yield of essential oil in the leaves was observed under red and blue colored shade net. The essential oil of the plants grown under red net showed the highest relative percentage of patchoulol $(66.84 \%)$. Therefore, it is possible using colored shade nets to manipulate $P$. cablin growth, as well as its essential oil production with several chemical compositions. The analyses of principal components allowed observing that pogostol has negative correlation with $\alpha$-guaiene and $\alpha$-bulnesene. There was difference in total dry weight and patchoulol content when the patchouli is cultured under the red colored shade nets.
\end{abstract}

Key words: light quality, patchouli, patchoulol, radiation intensity.

\section{INTRODUCTION}

Pogostemon cablin (Blanco) Benth. (Lamiaceae), commonly known as patchouli, is one of the medicinal herbal plants that produces essential oils (Rusydi et al. 2013). Patchouli has been cultivated in Indonesia, Malaysia, China, India, Singapore, Philippines, Brazil for the essential oil production

Correspondence to: José Eduardo Brasil Pereira Pinto

E-mail: jeduardo@dag.ufla.br because of its economic importance (Sukardi et al. 2017). About $80 \%$ of patchouli oil world demand is supplied by Indonesia and applied widely in perfumes, cosmetics, food, beverages, soap and even the last two decades, many medical worlds use as a medicinal ingredient (Hu et al. 2006). According to Swamy and Sinniah (2015), it has demonstrated to possess multibeneficial pharmacological properties, such as antimicrobial, antioxidant, analgesic, anti-inflammatory, antiplatelet, antithrombotic, 
aphrodisiac, antidepressant, antimutagenic, antiemetic, fibrinolytic and cytotoxic activities.

The plant growth analysis is the simplest and most accurate way to infer the contribution of different physiological processes between genetically different plants or if grown under different environmental conditions. It allows determining the plant biomass production kinetics, as well as its distribution and efficiency throughout ontogeny (Benincasa 2003).

Several factors affect plant growth; genetic and agronomic factors stand out among them. The amount and quality of light considerably affect plant growth and development. Crops grown under colored shade nets allow manipulating the incident solar light spectrum by fragmenting the direct light and converting it into diffused light to better cover the plants and stimulate photosynthesis (von Arnim and Deng 1996).

According to De Almeida and Mundstock (1998), the intensity and composition of the incident light influence cell growth rates, pigment accumulation and plastid differentiation in plants. The colored shade nets combine physical protection and differentiated solar radiation filtering to promote the desired physiological responses regulated by light (Shahak et al. 2004).

Studies about the physiological responses of medicinal and aromatic plants are of great importance, since they generate knowledge that makes it possible to develop cultivation techniques to achieve higher dry matter content and active ingredient levels. Studies about the cultivation of aromatic plants have found different responses concerning the vegetative growth and the content and composition of essential oil, according to the light spectrum control during cultivation (Martins et al. 2008, Brant et al. 2009, Costa et al. 2012).

The patchouli species is used on commercial scale; however, no studies reporting the cultivation of this species under the influence of colored shade nets were found in the literature. Thus, the aim of the current study is to assess the spectral quality effect of the light transmitted through these nets on the vegetative growth and anatomy, as well as on the content, essential oil yield and chemical composition of $P$. cablin leaves.

\section{MATERIALS AND METHODS}

\section{SCIONS OBTAINMENT}

Patchouli scions were produced through micropropagation, using axillary buds inoculated in MS medium added with $0.5 \mathrm{mg} \mathrm{L}^{-1} \mathrm{BAP}$ as explants. Subsequently, the shoots were individualized and propagated in MS medium, without growth regulators, in order to develop roots. Thirty (30) days later, the plantlets were transferred to plastic tubes containing Tropstrato $\mathrm{HA}^{\circledR}$ commercial substrate, and acclimatized in greenhouse for 30 days. The scions (approximately $10 \mathrm{~cm}$ long) were transplanted to $10 \mathrm{~L}$ pots containing soil, sand and cattle manure (3: 1: 1). Identification of the variety $P$. cablin was deposited in the Herbarium of Universidade Federal de Sergipe (Herbarium Voucher number 13,175).

\section{SCIONS CULTIVATION AND GROWTH ANALYSIS}

The plants were grown under full sunlight and under $50 \%$-shade black, blue and red nets $\left(\right.$ Chromatinet $\left.^{\circledR}\right)$. The experimental design followed a completely randomized block methodology (RBD), with four treatments and five repetitions in four pots (one plant per pot). The soil cultivation was kept at field capacity and subjected to alternating irrigations.

The growth assessments took place 150 days after planting, and the following parameters were set: leaf area (LA), which was measured in Leaf Area Electronic Meter, Model LI - 3100- LICOR, to find parameters such as leaf area ratio (ratio between total leaf area per plant and total dry weight - LAR), specific leaf area (ratio between total leaf area per plant and leaf dry weight - SLA) and leaf weight ratio (ratio between total leaf 
weight per plant and total dry weight per plant LWR), according to Benincasa (2003).

After the harvesting, each plant was partitioned into roots, stem and leaves, and placed in forced air circulation oven at $40^{\circ} \mathrm{C}$. The roots were also washed and oven dried. The leaf dry weight (LDW), shoot dry weight (SDW), root dry weight (RDW) and total dry weight (TDW) were measured in an analytical balance after the constant weight was reached.

\section{ANATOMY}

The leaf samples that had fully expanded in the third node from the apical bud were collected and fixed to enable studying their anatomical components.

The anatomical studies were performed in $2 \times 5 \mathrm{~mm}$ fragments of the mid-blade region. These fragments were sectioned and fixed in modified Karnovsky's - 2.5\% glutaraldehyde, $2.5 \%$ formaldehyde in $0.05 \mathrm{M}$ sodium cacodylate buffer, $\mathrm{pH} 7.2, \mathrm{CaCl}_{2} 0.001 \mathrm{M}$. The sections kept in this solution were stored in refrigerator for further analysis. The paradermic sections were washed three times in sodium cacodylate buffer, post-fixed in $1 \%$ osmium tetroxide for 2 hours, and washed twice in distilled water for 15 minutes. Each material selected for scanning microscopy was dehydrated in progressive acetone gradients (25\%, 50\%, 75\%, 90\% and 100\%) for 10 minutes. The cross sections were obtained by immersing the samples in $30 \%$ glycerol solution in distilled water for 30 minutes. Next, they were frozen in liquid nitrogen and fractured with scalpel. These sections were post-fixed in osmium tetroxide (Alves et al. 2008).

Subsequently, this material was dried to the critical point (BAL-TEC, model CPD-030, Principality of Liechtenstein) and mounted on aluminum stubs using double-sided tape in order to receive metalized cover in gold evaporator Sputtering (BAL-TEC, model SCD-050,
Principality of Liechtenstein). All sections were analyzed in scanning electron microscope (LEO, model EVO 40 XVP, Cambridge - UK). The anatomical components observed in the cross sections were abaxial and adaxial epidermis, cuticle, palisade and spongy parenchyma, and leaf blade thicknesses. Trichome and stomatal density (presence and amount of trichomes), polar diameter (PD) and equatorial diameter (ED) were observed in the paradermal sections (Alves et al. 2008).

\section{ESSENTIAL OIL EXTRACTION}

The essential oil was extracted through hydrodistillation in a modified Clevenger apparatus for 90 minutes, using individual $70 \mathrm{~g}$ and $40 \mathrm{~g}$ leaf and shoot dry weight samples, respectively, in $1.5 \mathrm{~L}$ distilled water. Subsequently, the liquid-liquid partitioning was performed using dichloromethane $(3 \times 10 \mathrm{~m} \mathrm{~L})$. Two grams $(2 \mathrm{~g})$ of anhydrous magnesium sulfate were added to the combined organic fraction. The solution was filtered and the organic solvent was evaporated at room temperature under gas exhaust hood. The essential oil was stored in amber glass bottles; its matters were measured and stored in refrigerator at $\pm 4^{\circ} \mathrm{C}$, for further analysis. The parameters used to quantify the essential oil were leaf dry weight (LDW) and shoot dry weight (SDW) content and yield. The essential oil content was directly calculated in percentage (g.100g ${ }^{-1}$ LDW) and the essential oil yield was calculated through the following equation: (Content x LDW), whose yield unit was expressed as g plant ${ }^{-1}$.

\section{THE CHEMICAL ANALYSIS OF THE ESSENTIAL OIL}

Five repetitions per treatment were performed in order to analyze the essential oil of the leaves. A composite sample was prepared to analyze the essential oil of the stem and it consisted of aliquots contained in equivalent volumes of the essential oils from the five repetitions of each treatment. 
The quantitative analysis of the essential oil was carried out in a gas chromatograph coupled with a hydrogen Flame Ionization Detector (GCFID) in an Agilent ${ }^{\circledR} 7890^{a}$ system, which was equipped with a DB-WAX J \& W 122-7032 column (30 m length $\times 0.25 \mathrm{~mm}$ internal diameter $\times 0.25$ $\mu \mathrm{m}$ thick film) (California, USA). Helium was used as carrier gas at flow $1.0 \mathrm{ml} / \mathrm{min}$; the temperature was kept at $240^{\circ} \mathrm{C}$ in both the injector and the detector. The initial temperature was $100^{\circ} \mathrm{C}$, it was followed by a temperature ramp of $3^{\circ} \mathrm{C} / \mathrm{min}$ up to $180^{\circ} \mathrm{C}$ and ended with a temperature ramp of $10^{\circ} \mathrm{C} / \mathrm{min}$ up to $240^{\circ} \mathrm{C}$. The oil was diluted in ethyl acetate $(1 \%, \mathrm{v} / \mathrm{v})$ and automatically injected into the chromatograph $(1 \mu \mathrm{L}$ volume injection), using split mode at injection ratio 50:1. The content of the eluted constituents was expressed through the mean rate of the area relative to the chromatographic peaks \pm the standard deviation of the analyzed samples.

The qualitative analysis of the oil was performed in a gas chromatograph coupled to a selective mass detector (GC-MS), using the Agilent ${ }^{\circledR} 5975 \mathrm{C}$ equipment, which was operated through electronic impact ionization at $70 \mathrm{eV}$, in scan mode, at speed $1.0 \mathrm{scan} / \mathrm{s}$ and mass acquisition interval 40-400 $\mathrm{m} / \mathrm{z}$. The chromatographic conditions were the same ones used in the quantitative analysis. The chemical constituents were tentative identified by linear retention index (Van den Dool and Kratz 1963 ) and the exactly match of the mass spectra of the analytical peaks with those of NIST/EPA/NIH library (NIST 2008) and (Deguery et al. 2006).

\section{STATISTICAL ANALYSIS}

The statistical analysis of the observed data was performed according to the $\mathrm{R}$ Development Core Team (2012). The treatment means were subjected to Tukey's test at 5\% probability. Standardized data of three replicate were subjected to multivariate analysis, i.e., principal component analysis
(PCA), using Statistica software (trial version 12, StatSoft Inc., USA) for the assessment of chemical composition (loadings) diversity of patchouli plants treated with several of colored shade nets (scores). The eigenvalues were: 5.414, 1.155 and below 1 for the remaining PCs. The first two principal components together explained $93.84 \%$ of the total variance, and they were included in the discussion. Correlation-based PCA of major compounds constituents (including $\alpha$-Guaiene, $\alpha$-Patchoulene, Seychellene, $\alpha$-Bulnesene, Patchoulol, Pogostol) and TDW contained in patchouli plants was performed.

\section{RESULTS AND DISCUSSION}

The cultivation under colored shade nets has significantly affected the growth of $P$. cablin plants. The accumulation of leaf, stem and total dry weight was affected by the use of colored shade nets, when they were compared to plants grown under full sunlight (Figure 1). Such accumulation was higher in the leaves $(46.70 \mathrm{~g})$ and stems (31.84 g) when the plants were grown under red net. Consequently, there was greater accumulation of total dry weight (93.81 g).

These results may be associated with the higher incidence of photons in the red and far-red region. Such incidence favored the photosynthetic process and it suggests that the red net has stimulated vegetative growth and vigor. The blue net has decreased the rays in the far-red band and the black net has not changed the quality of the radiation (Costa et al. 2012).

The plants of $P$. cablin grown under full sunlight have allocated higher amounts of assimilates to the roots and showed the highest root-shoot ratio (0.33) in comparison with black $(0.21)$, blue (0.20) and red (0.19) (data not shown). This allocation may have been occurred due to light intensity, which made plants invest in root growth as adaptive strategy to increase their 


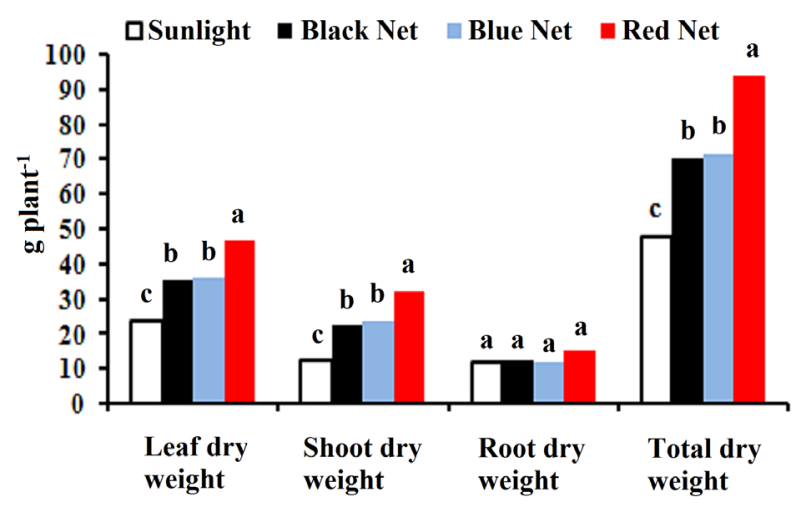

Figure 1 - Leaf dry weight (LDW), shoot dry weight (SDW), root dry weight (RDW) and total dry weight (TDW) of $P$. cablin grown under full sun and under black, blue and red nets at $50 \%$ shading.

water and nutrient absorption capacity. The same behavior was found in other species grown under experimental conditions similar to those applied to patchouli plants (Melo and de Alvarenga 2009, Martins et al. 2008, Oliveira et al. 2009)

It is noteworthy that these results may be related to the fact that patchouli plants are able to adapt to shade conditions. Especially when they are intercropped with plants able to provide them with shading (Ram et al. 1999).

The variable total dry weight (TDW) was influenced by the cultivation environment. Such environment has also influenced the leaf area increase in all the herein tested treatments due to light intensity and to light spectral quality. The largest leaf area was found in plants grown under red net $\left(43.55 \mathrm{~cm}^{2}\right)$, whereas the smallest one was observed in plants grown under full sunlight (17.23 $\mathrm{cm}^{2}$ ), as shown in Figure 2.

The plants subjected to low irradiance levels have expanded their leaves to enhance light energy capture and to achieve greater photosynthetic efficiency; consequently, they have increased carbon fixation (Taiz and Zeiger 2009).

The indices shown in Figure 2 allowed observing that the LAR (LA/TDW) increase was the strategy used by plants to adapt to low lighting.
The lowest LAR was recorded in plants grown under full sunlight $\left(0.36 \mathrm{~cm}^{2} \mathrm{~g}^{-1}\right)$. It has increased under the black and red nets $\left(0.46 \mathrm{~cm}^{2} \mathrm{~g}^{-1}\right)$ and reached its peak under the blue net $\left(0.52 \mathrm{~cm}^{2} \mathrm{~g}^{-1}\right)$. This result is an indication that $P$. cablin plants grown under blue net require greater leaf area to produce one gram of dry matter in comparison to the others treatments.

Since leaves are the main plant parts responsible for biomass production and the rest of the plant depends on biomass transportation (Benincasa 2003), the leaf weight ratio (LWR) represents such expression (LDW/TDW). All the treatments have statistically shown the same LWR, and it has proved the productive efficiency of the treatments in dry mass production, when it was compared to the weight of the entire plant.

The specific leaf area (SLA=LA/LDW), which is an indication of the leaf thickness, is used to estimate the assimilation ratio, as well as the supporting and conducting leaf tissues. The SLA was lower under full sunlight condition, and it indicated that $P$. cablin leaves became thicker when the plants were kept under no shading. Such results meet those found in Aloysia gratissima, which has shown the lowest SLA under full sunlight condition and slightly thinner leaves under red, blue and black nets (dos Santos 2007).

Anatomical observations of $P$. cablin leaves were performed through scanning electron microscopy and the results have shown that cultivations grown under colored shade nets and under full sunlight have affected leaf morphology (Table I, Figure 3). The thicknesses of the abaxial and adaxial epidermis, as well as the cuticle thickness, were higher in plants grown under full sunlight, and it shows that increased radiation tends to increase leaf thickness in $P$. cablin.

Castro et al. (2007) have studied Mikania glomerata Sprengel (Asteraceae) plants grown under different shading levels and found thicker epidermis in plants grown under full sunlight 
conditions. In Aloysia gratissima, the similar results were found by Pinto et al. (2007). The reduction in leaf thickness of shaded plants is possibly due to the difference in distribution and consumption of photoassimilates for leaf expansion (Martins et al. 2009). In this research, plants under red nets showed the highest leaf area (Figure 2) and smaller thicknesses of the abaxial and cuticle thickness (Table I).

Palisade parenchyma thickness (PP) was higher under red $(61.38 \mu \mathrm{m})$ and blue $(65.97 \mu \mathrm{m})$ net (Table I). However, in the spongy parenchyma
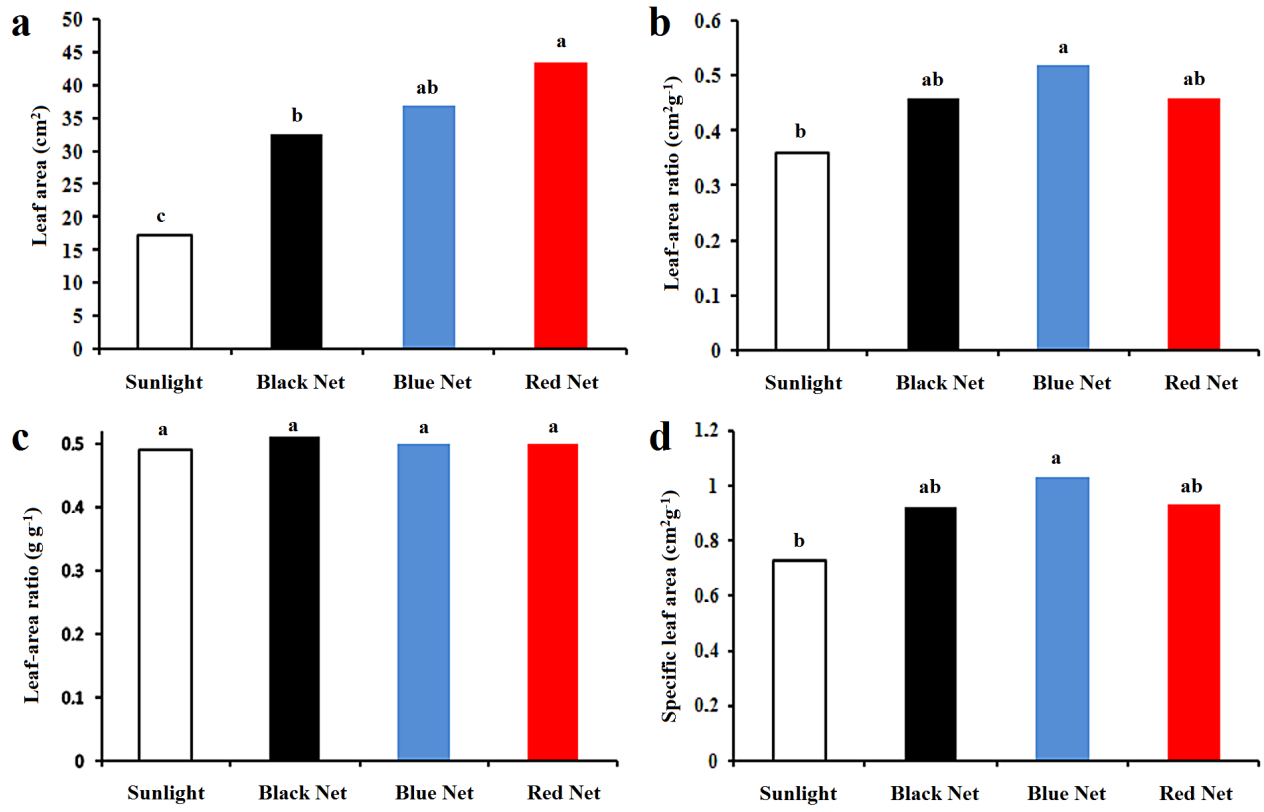

Figure 2 - a) Leaf area (LA) $\left(\mathrm{cm}^{2}\right)$, b) leaf area ratio (LAR) $\left(\mathrm{cm}^{2} \mathrm{~g}^{-1}\right)$, c) leaf weight ratio (LWR) (g $\left.\mathrm{g}^{-1}\right)$ and d) specific leaf area (SLA) $\left(\mathrm{cm}^{2} \mathrm{~g}^{-1}\right)$ of $P$. cablin grown under full sun and under black, blue and red nets at $50 \%$ shading.

TABLE I

Epidermal thickness in the adaxial face (EAD), epidermal thickness in the abaxial face (EAB), cuticle thickness (CUT), palisade parenchyma thickness (PP), spongy parenchyma thickness (SP) and leaf blade thickness (LB). Leaf tissue features in a cross section of $P$. cablin grown under full sun and under colored shade nets, at $50 \%$ shading.

\begin{tabular}{ccccccc} 
& EAD & EAB & CUT & PP & SP & LB \\
\cline { 2 - 7 } TREAT. & & & $(\boldsymbol{\mu m})$ & & & \\
\hline Red & $18.59 \mathrm{ab}^{1}$ & $14.43 \mathrm{~b}$ & $2.21 \mathrm{c}$ & $61.38 \mathrm{a}$ & $147.66 \mathrm{a}$ & $258.56 \mathrm{a}$ \\
Blue & $16.69 \mathrm{~b}$ & $17.60 \mathrm{a}$ & $2.45 \mathrm{~b}$ & $65.97 \mathrm{a}$ & $85.31 \mathrm{~b}$ & $150.62 \mathrm{~b}$ \\
Black & $15.99 \mathrm{~b}$ & $16.92 \mathrm{a}$ & $2.36 \mathrm{~b}$ & $29.65 \mathrm{c}$ & $71.45 \mathrm{~b}$ & $135.30 \mathrm{~b}$ \\
Full sun & $23.47 \mathrm{a}$ & $16.40 \mathrm{a}$ & $6.55 \mathrm{a}$ & $51.72 \mathrm{~b}$ & $169.12 \mathrm{a}$ & $289.98 \mathrm{a}$ \\
\hline CV\% & 17.42 & 5.65 & 2.23 & 7.39 & 12.46 & 10.70
\end{tabular}

${ }^{1}$ Means followed by the same letter do not differ from each other, according to the Tukey's test at 5\% significance. 


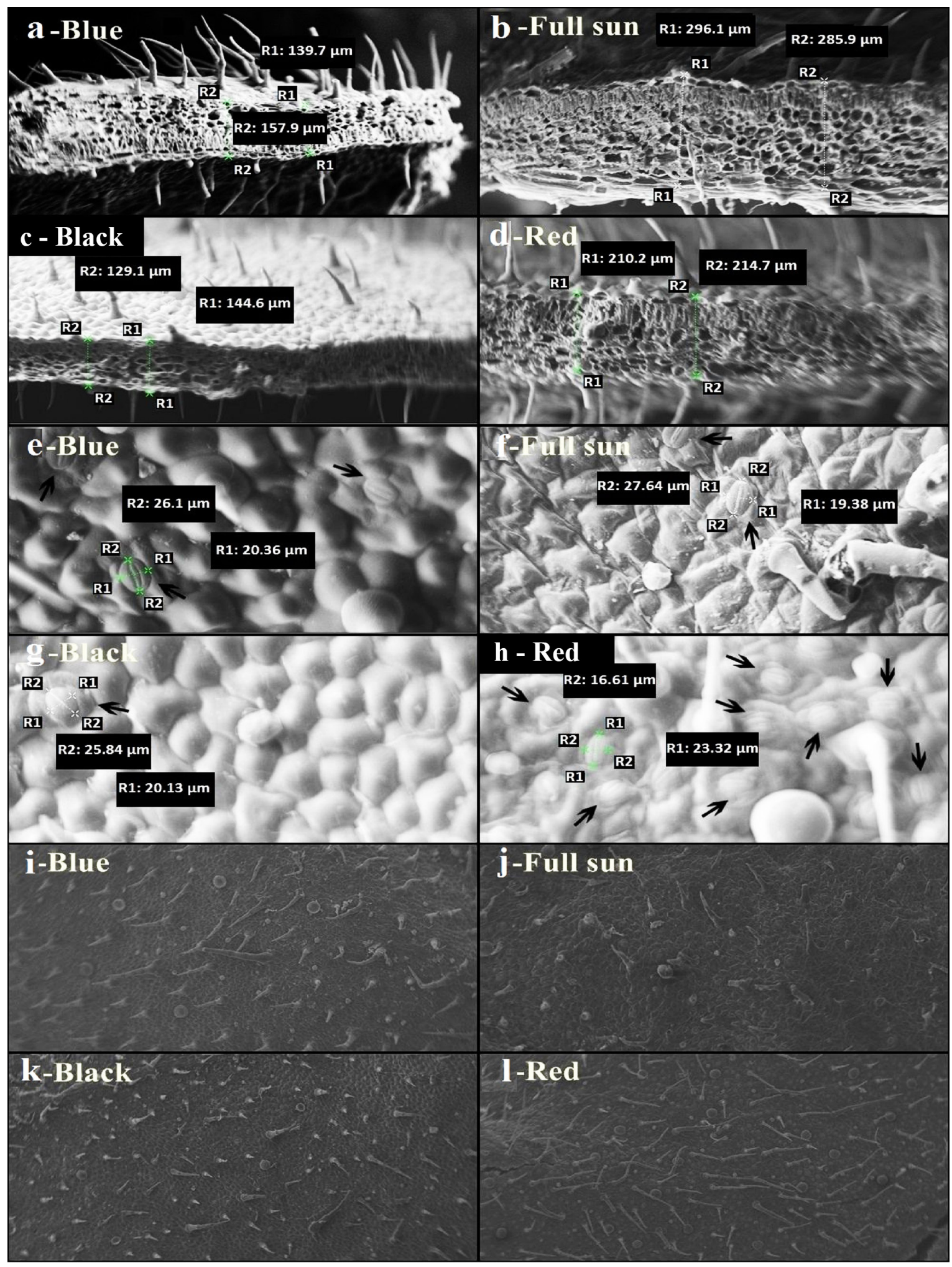

Figure 3 - Photomicrographs of $P$. cablin leaves grown under full sun and under colored shade nets at 50\% irradiance. a - d) Leaf blade thickness; $\mathbf{e}$ - h) equatorial and polar diameter of stomata in the abaxial face; $\mathbf{i}$ - I) number of trichomes in the abaxial face epidermis. Arrows showing the stomata. 
TABLE II

Number of trichomes in the adaxial epidermis (TAD), stomatal density in the adaxial epidermis (SDAD), polar and equatorial diameter of the stomata ratio (PD/ED) in the adaxial faces, number of trichomes in the abaxial epidermis (TAB), stomatal density in the abaxial epidermis (SDAB) and polar and equatorial diameter of the stomata ratio (PD/ED) in the abaxial faces of $\boldsymbol{P}$. cablin cultivated under colored shade nets and under full sun.

\begin{tabular}{|c|c|c|c|c|c|c|}
\hline \multirow[b]{2}{*}{ TREAT. } & \multicolumn{3}{|c|}{-------------Adaxial Face-------------- } & \multicolumn{3}{|c|}{--------------------Abaxial Face------------------- } \\
\hline & TAD & $\begin{array}{l}\text { SDAD } \\
\left(\mu \mathrm{m}^{-2}\right)\end{array}$ & PD/ED & TAB & $\begin{array}{l}\text { SDAB } \\
\left(\mu \mathrm{m}^{-2}\right)\end{array}$ & PD/ED \\
\hline Red & $52.00 \mathrm{c}^{1}$ & $1.67 \mathrm{~b}$ & $1.44 \mathrm{a}$ & $121.00 \mathrm{a}$ & $12.00 \mathrm{a}$ & $1.48 \mathrm{a}$ \\
\hline Blue & $24.00 \mathrm{~d}$ & $2.67 \mathrm{~b}$ & $1.21 \mathrm{c}$ & $86.67 \mathrm{~b}$ & $5.00 \mathrm{c}$ & $1.29 \mathrm{ab}$ \\
\hline Black & $69.00 \mathrm{~b}$ & $1.67 \mathrm{~b}$ & $1.29 \mathrm{c}$ & $53.00 \mathrm{c}$ & $3.00 \mathrm{c}$ & $1.15 \mathrm{~b}$ \\
\hline Full sun & $72.00 \mathrm{a}$ & $5.00 \mathrm{a}$ & $0.92 \mathrm{~d}$ & $56.00 \mathrm{c}$ & $9.00 \mathrm{~b}$ & $1.20 \mathrm{~b}$ \\
\hline $\mathrm{CV} \%$ & 1.84 & 25.71 & 0.43 & 1.82 & 13.79 & 6.83 \\
\hline
\end{tabular}

${ }^{1}$ Means followed by the same letter did not differ from each other, according to the Tukey's test at 5\% significance.

of trichomes and stomata. The higher number of trichomes (72) and stomatal density $\left(5 \mu \mathrm{m}^{-2}\right)$ in the adaxial face was observed under full sunlight. However, in the abaxial epidermis the number of trichomes (121) and stomatal density $\left(12 \mu \mathrm{m}^{-2}\right)$ was observed under red net (Figure 3e-1). Trichomes are a form of morphological adaptation that may protect plants by regulating leaf temperature through light reflection and the glandular trichomes may secret substances in order to protect the leaves from parasites and predators (Barboza et al. 2006).

The stomata are important structures in plant productivity, since they represent the entrance and exit doors of photosynthesis gases (Silva et al. 2005). The variations of the stomatal densities on the adaxial and abaxial surfaces reveal the anatomical plasticity of $P$. cablin as a function of the culture environment. According to Martins et al. (2009), the increase in stomatal density is generally related to greater stomatal conductance, avoiding that photosynthesis is limited under adverse conditions.

The plants submitted to shading with red net had a higher polar/equatorial diameter ratio on the abaxial and adaxial surfaces (Table II, Figure 3e-h). According to Sha Valli Khan et al. (2002), the higher the $\mathrm{PD} / \mathrm{ED}$ ratio, the more ellipsoid the stomata and it may result in greater functionality. Thus, the treatments under full sunlight, as well as under blue and black nets, have shown less functional stomata in both the abaxial and the adaxial faces. This greater functionality of the stomata under red net brought higher leaf dry weight and consequently more total dry weight for P. cablin (Figure 1).

Changes in this ellipsoid structure affect stomata opening and closing controls, and it results in high stomatal conductance, fact that favors water loss. The blue and red light spectra are important to control the stomata opening since they regulate the phototropins and phytochromes that activate a signaling cascade to control the stomata opening and closing (Chen et al. 2012, Shimazaki et al. 2007).

The essential oil content and yield in the leaves has observed higher amount than stem (Table III). The highest essential oil content $(1.13 \%)$ was found in plants grown under blue net. However, the leaves dry weight under red net was 31\% higher than under blue net. Although these results of content and dry weight were different under blue and red net, the yield productions were similar between treatments. The other treatments did not present statistically different essential oil contents and yield. The essential oil yield of the plants grown under full sunlight have presented the lowest yield $\left(0.18\right.$ g plant $\left.^{-1}\right)$.

Souza et al. (2011) have conducted studies using Mikania laevigata and Mikania glomerata 
grown under red, gray and blue nets, as well as under full sunlight, and found similar results. Mikania glomerata has shown the highest essential oil content under blue net, whereas Mikania laevigata has shown the highest essential oil content under red net. Both species have shown the lowest essential oil values when they were cultivated under full sunlight. Chagas et al. (2011) have cultivated Mentha arvensis under colored shade nets and found that the essential oil yield decreased in comparison to that of plants grown under full sunlight. On the other hand, Costa et al. (2012) have cultivated Mentha piperita and found favorable results for essential oil production and composition. Plants grown under black and blue nets have shown the highest menthofuran contents.

Brant et al. (2009) have studied Melissa officinalis grown under the same conditions and found results different from those found in the current study, wherein the essential oil content and yield did not have a positive response to the use of red net. The quality of the Melissa officinalis essential oil presented the best amount of citral under red net, which is a major compound of great interest in melissa species. On the other hand, Oliveira et al. (2016) have reported Melissa officinalis plants grown under shade from blue net showed the highest essential oil yield and red net resulted in a reduction in the yield of essential oil in leaves.

The environment where plants develop in, cultivation type, temperature, light intensity, humidity, as well as other factors, influence the chemical composition of essential oils. Since secondary metabolites represent a chemical interface between plants and surrounding environment, their syntheses are frequently affected by environmental conditions. Thus, variations in the total content and/or of the relative proportions of secondary metabolites in plants can take place (Gobbo-Neto and Lopes 2007). Silva et al. (2017) have reported that it is possible optimizing the growth and carvacrol content in Plectranthus amboinicus cultivated in vitro by adjusting these environmental parameters.

The chemical composition of the essential oil from $P$. cablin leaves grown in the different environments assessed in the current study entirely consisted of sesquiterpenes, except for 1-octen-3-ol alcohol, which was found at concentrations from $0.45 \%$ to $0.61 \%$ (Table IV). Thus, it corroborates the study by Yahya and Yunus (2013).

The chemical characterization of patchouli essential oil is already well reported in literature (Deguerry et al. 2006, Yahya and Yunus 2013, Fritri et al. 2017). Our achieved qualitative and quantitative chemical composition are in agreement with Friti et al. (2017). Constituents such as $\beta$-patchoulene, $\alpha$-guaiene, $\beta$-caryophyllene, $\alpha$-humulene and, especially, patchoulol presented similar ranges contents between the present study and the results reported by Friti et al. (2017).

Fifteen (15) chemical constituents were identified in the present study from $P$. cablin leaves. According to the quantitative analysis, more than $93 \%$ of the total chemical composition was elucidated. Six (6) out of these 15 components have constituted approximately $86 \%$ of the total chemical composition, and they were featured as $\alpha$-guaiene, $\alpha$-patchoulene, seychellene, $\alpha$-bulnesene, patchoulol and pogostol. Patchoulol has shown the highest contents among these components, between $62.10 \%$ and $66.84 \%$.

The relative percentage of patchoulol in the current study was 3 to 4 times higher than that reported by Milchard (2004) in essential oils from China (15\% to $24 \%$ ) and approximately 2 times higher than the contents quantified in essential oils from Indonesia (30\% to $33 \%$ ). However, it was close to the patchoulol concentration range $(50 \%$ to $64 \%$ ) found in the essential oil of patchouli leaves grown in Sergipe State, Brazil (de Sant'ana et al. 2010). 
TABLE III

Essential oil content and yield of $P$. cablin leaves and shoot grown under full sun and under colored shade nets.

\begin{tabular}{|c|c|c|c|c|}
\hline \multirow[b]{2}{*}{ TREATMENTS } & \multicolumn{2}{|c|}{ Leaf } & \multicolumn{2}{|c|}{ Shoot } \\
\hline & Content (\%) & $\begin{array}{c}\text { Yield } \\
\left(\text { g plant }^{-1}\right)\end{array}$ & Content (\%) & $\begin{array}{c}\text { Yield } \\
\left(\text { g plant }^{-1}\right)\end{array}$ \\
\hline Red & $0.72 b^{1}$ & $0.34 \mathrm{a}$ & $0.07 \mathrm{a}$ & $0.02 \mathrm{a}$ \\
\hline Blue & $1.13 \mathrm{a}$ & $0.41 \mathrm{a}$ & $0.05 \mathrm{a}$ & $0.01 \mathrm{~b}$ \\
\hline Black & $0.66 \mathrm{~b}$ & $0.23 \mathrm{~b}$ & $0.07 \mathrm{a}$ & $0.02 \mathrm{a}$ \\
\hline Full sun & $0.78 \mathrm{~b}$ & $0.18 \mathrm{~b}$ & $0.07 \mathrm{a}$ & $0.01 \mathrm{~b}$ \\
\hline $\mathrm{CV} \%$ & 19.34 & 18.77 & 29.91 & 28.83 \\
\hline
\end{tabular}

${ }^{1}$ Means followed by the same letter in the column did not significantly differ from each other, according to the Tukey's test, at $5 \%$ significance.

TABLE IV

Chemical composition of the essential oil from $P$. cablin leaves grown under full sun and under colored shade nets.

\begin{tabular}{ccccccc}
\hline \multirow{2}{*}{ Peak } & Constituents & \multirow{2}{*}{ RI* } & \multicolumn{4}{c}{ TREATMENTS - Area (\%) \pm SD } \\
\cline { 4 - 7 } & & & Full sun & Black & Blue & Red \\
\hline 1 & 1 -Octen 3-ol & 1412 & $0.61 \pm 0.06$ & $0.48 \pm 0.24$ & $0.45 \pm 0.13$ & $0.46 \pm 0.17$ \\
2 & $\beta$-Patchoulene & 1457 & $0.80 \pm 0.05$ & $1.06 \pm 0.13$ & $1.02 \pm 0.11$ & $0.81 \pm 0.88$ \\
3 & $\alpha$-Guaiene & 1547 & $4.49 \pm 0.32$ & $6.14 \pm 0.46$ & $6.12 \pm 0.71$ & $4.38 \pm 4.95$ \\
4 & $\beta$-Caryophyllene & 1557 & $1.45 \pm 0.06$ & $1.79 \pm 0.19$ & $1.76 \pm 0.21$ & $1.19 \pm 1.37$ \\
5 & $\alpha$-Patchoulene & 1599 & $2.04 \pm 0.09$ & $2.35 \pm 0.33$ & $2.24 \pm 0.17$ & $1.92 \pm 1.93$ \\
6 & Seychellene & 1605 & $4.62 \pm 0.22$ & $5.01 \pm 0.79$ & $4.85 \pm 0.36$ & $4.47 \pm 3.72$ \\
7 & $\gamma$-Patchoulene & 1621 & $0.52 \pm 0.03$ & $0.55 \pm 0.10$ & $0.53 \pm 0.04$ & $0.50 \pm 0.39$ \\
8 & $\alpha$-Humulene & 1631 & $0.45 \pm 0.02$ & $0.56 \pm 0.04$ & $0.56 \pm 0.06$ & $0.40 \pm 0.45$ \\
9 & $\alpha$-Bulnesene & 1680 & $5.26 \pm 0.16$ & $6.65 \pm 0.75$ & $6.63 \pm 0.83$ & $4.53 \pm 5.09$ \\
10 & Caryophyllene oxide & 1998 & $1.22 \pm 0.12$ & $0.99 \pm 0.25$ & $0.99 \pm 0.17$ & $1.70 \pm 0.77$ \\
11 & Norpatchoulenol & 2152 & $1.29 \pm 0.13$ & $1.01 \pm 0.13$ & $0.94 \pm 0.06$ & $1.00 \pm 0.98$ \\
12 & Spathulenol & 2158 & $0.72 \pm 0.03$ & $0.74 \pm 0.08$ & $0.78 \pm 0.12$ & $1.03 \pm 0.72$ \\
13 & Patchoulol & 2233 & $65.68 \pm 0.90$ & $62.45 \pm 3.02$ & $62.10 \pm 1.99$ & $66.84 \pm 2.55$ \\
14 & $\beta$-Selinene & 2262 & $0.66 \pm 0.01$ & $0.60 \pm 0.03$ & $0.60 \pm 0.02$ & $0.65 \pm 0.57$ \\
15 & Pogostol & 2267 & $4.46 \pm 0.13$ & $4.04 \pm 0.32$ & $4.08 \pm 0.14$ & $4.34 \pm 4.08$ \\
& Total identified (\%) & & 94.27 & 94.42 & 93.65 & 94.22 \\
\hline
\end{tabular}

Retention index on the DB-Wax column. SD: Standard Deviation $(n=5)$.

Plants of $P$. cablin grown under full sunlight and under colored shade nets, the patchoulol contents were slightly higher in the essential oil from plants grown under full sunlight (65.68\%) and under red net $(66.84 \%)$. On the other hand, there was slight $\alpha$-patchoulene decrease in patchouli leaves grown under red net $(1.92 \%)$ in comparison to those subjected to the other treatments $(2.04 \%$ to $2.35 \%)$. Patchoulol and $\alpha$-patchoulene are constituents of great commercial interest in perfume industries
(Mekem Sonwa 2000). Although the $\alpha$-patchoulene is found in small amounts, it is an important constituent of the patchouli essential oil since, in combination with patchoulol, it determines the oil aroma (Donelian et al. 2009).

The light spectral quality affects the $P$. cablin essential oil production and its chemical composition, since it is known that patchouli shows the best vegetative growth rates in plants grown under shading conditions. Therefore, it was 
$\mathbf{a}$

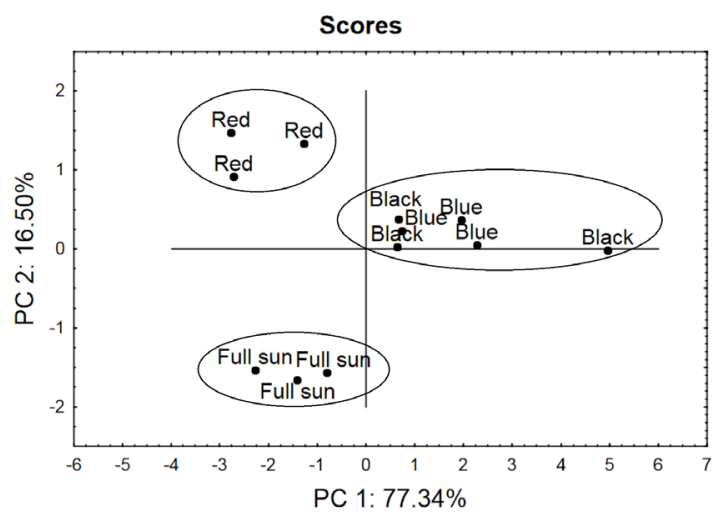

b

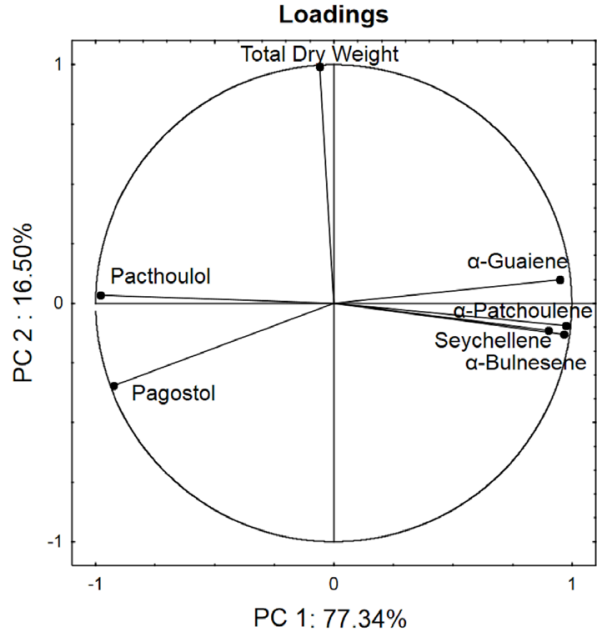

Figure 4 - Scores (a) and Loadings (b) of the principal components analyses (PCA) on the matrix correlation built using data for six major compound and total dry weight of $P$. cablin.

concluded that the red and blue nets were the best cultivation alternatives.

The resulting of the principal components analyses, scores (a) and loadings (b), provides a conceptual overview of the treatments by showing a total of $93.84 \%$ of the variance (Figure 4 ). PCs separated these treatments in three groups blue and black from red colored shade net and full sun (Figure 4a). The analyses of loadings allowed observing the most important variables were the essential oil compounds by PC1 and in total dry weight by PC2. Taking into account the highest loading of PC1, it is possible to conclude that patchouli illuminated with red colored shade nets showed higher total dry weight and patchoulol content (Figure 4b).
The plants cultivated in full sun light had more concentration of pogostol and lower total dry weight. It can observe that the black and blue colored shade nets had higher content of compounds ( $\alpha$-guaiene, $\alpha$-patchoulene, seychellene, $\alpha$-bulnesene). These compounds are negatively correlated to patchoulol and pogostol. The analyses of loadings allowed observing that pogostol is negative correlation with $\alpha$-guaiene and $\alpha$-bulnesene. This can be explained because these compounds have the guaianyl cation as the same precursor in the pathway (Deguerry et al 2006). Overall evaluation of the dates it is noteworthy that there is difference in total dry weight and patchoulol content when the patchouli is cultured under the red colored shade nets.

\section{ACKNOWLEDGMENTS}

The authors would like to thank Conselho Nacional de Desenvolvimento Científico e Tecnológico (CNPq), Coordenação de Aperfeiçoamento de Pessoal de Nível Superior (CAPES) and Fundação de Pesquisa do Estado de Minas Gerais (FAPEMIG) for the financial support (scholarships and research grants).

\section{REFERENCES}

ALVES E, LEITE B, MARUCCI RC, PASCHOLATI SF, LOPES JRS AND ANDERSEN PC. 2008. Retention sites for Xylella fastidiosa in four sharpshooter vectors (Hemiptera: Cicadellidae) analyzed by scanning electron microscopy. Curr Microbiol 56: 531-538.

BARBOZA SBSC, GRACIANO-RIBEIRO D, TEIXEIRA JB, PORTES TA AND SOUZA LAC. 2006. Anatomia foliar de plantas micropropagadas de abacaxi. Pesq Agropec Bras 41: 185-194.

BENINCASA MMP. 2003. Análise de crescimento de plantas: noções básicas, $1^{a}$ ed., Jaboticabal: FUNEP, 41 p.

BRANT RS, PINTO JEBP, ROSA LF, ALBUQUERQUE CJB, FERRI PH AND CORREAA RM. 2009. Crescimento, teor e composição do óleo essencial de melissa cultivada sob malhas fotoconversoras. Cienc Rural 39: 1401-1407.

CASTRO EM, PINTO JEBP, SOARES AM, MELO HC, BERTALUCCI SKV, VIEIRA CV AND LIMA JÚNIOR EC. 2007. Adaptações anatômicas de folhas de Mikania glomerata Sprengel (Asteraceae), em três regiões distintas 
da planta, em diferentes níveis de sombreamento. Rev Bras P1 Med 9: 8-16.

CHAGAS JH, PINTO JEBP, BERTOLUCCI SKV AND DO SANTOS FM. 2011. Produção de biomassa e teor de óleo essencial em função da idade e época de colheita em plantas de hortelã-japonesa. Acta Sci - Agron 33: 327334.

CHEN ZH, HILLS A, BÄTZ U, AMTMANN A, LEW VL AND BLATT MR. 2012. Systems dynamic modeling of the stomatal guard cell predicts emergent behaviors in transport, signaling, and volume control. Plant Physiol 159: 1235-1251.

COSTAAG, CHAGAS JH, PINTO JEBP AND BERTOLUCCI SKV. 2012. Crescimento vegetativo e produção de óleo essencial de hortelã pimenta cultivada sob malhas. Pesq Agropec Bras 47: 534-540.

DE ALMEIDA ML AND MUNDSTOCK CM. 1998. O afilhamento em comunidades de cereais de estação fria é afetado pela qualidade da luz? Cienc Rural 28: 511-519.

DE SANT'ANA TCP, BLANK AF, VIEIRA SD, ARRIGONIBLANK MDF, DE JESUS HCR AND ALVES PB. 2010. Influência do armazenamento de folhas secas no óleo essencial de patchouli (Pogostemon cablin Benth.). Quim Nova 33: 1263-1265.

DEGUERRY F, PASTORE L, WU S, CLARK A, CHAPPELL J AND SCHALK M. 2006. The diverse sesquiterpene profile of patchouli, Pogostemon cablin, is correlated with a limited number of sesquiterpene synthases. Arch Biochem Biophys 454: 123-136.

DONELIAN A, CARLSON LHC, LOPES TJ AND MACHADO RAF. 2009. Comparison of extraction of patchouli (Pogostemon cablin) essential oil with supercritical $\mathrm{CO}_{2}$ and by steam distillation. J Supercrit Fluids 48: 15-20.

DOS SANTOS FM. 2007. Aspectos ecofisiológicos de Aloysia gratissima (Gillies et Hook) Troncoso [Verbenaceae] associados à composição do óleo essencial e sua ação antimicrobiana. Tese de Mestrado. Lavras: UFLA, 116 p. (Unpublished).

FITRI N, YANDI N, HERMAWATI D AND JULIANTO TS. 2017. A comparative study of water-steam distillation with water-bubble distillationtechniques to increase the quality of patchouli essential oil. AIP Conference Proceedings 1823: 020122.

GOBBO-NETO L AND LOPES N. 2007. Plantas medicinais: fatores de influência no conteúdo de metabólitos secundários. Quim Nova 30: 374-381.

HU LF, LI SP, CAO H, LIU JJ, GAO JL, YANG FQ AND WANG YT. 2006. GC-MS fingerprint of Pogostemon cablin in China. J Pharm Biomed Anal 42: 200-206.

LEE DW, OBERBAUER SF, JOHNSON P, KRISHNAPILAY B, MANSOR M, MOHAMAD H AND YAP SK. 2000. Effects of irradiance and spectral quality on leaf structure and function in seedlings of two Southeast Asian Hopea (Dipterocarpaceae) species. Am J Bot 87: 447-455.

MARTINS JR, ALVARENGA AA, CASTRO EM, PINTO JEBP AND SILVA APO. 2008. Avaliação do crescimento e do teor de óleo essencial em plantas de Ocimum gratissimum L. cultivadas sob malhas coloridas. Rev Bras Pl Med 10: 102-107.

MARTINS JR, ALVARENGA AA, CASTRO EMD, SILVA APOD, OLIVEIRA C AND ALVES E. 2009. Anatomia foliar de plantas de alfavaca-cravo cultivadas sob malhas coloridas. Cienc Rural 39: 82-87.

MELO AAM AND DE ALVARENGA AA. 2009. Sombreamento de plantas de Catharanthus roseus (L.) G. Don 'Pacifica White'por malhas coloridas: desenvolvimento vegetativo. Cienc Agrotec 33: 514-520.

MILCHARD MJ, CLERY R, DACOSTA N, ESDALE R, FLOWERDEW M, GATES L, MOSS N, MOYLER DA, SHERLOCK A AND STARR B. 2004. Application of gas-liquid chromatography to the analysis of essential oils fingerprints of 12 essential oils. Perfumer \& Flavorist 29: 28-36.

NIST. 2008. PC version 2.0 of the NIST/EPA/NIH mass spectral library. Gaithersburg: National Institute of Standards and Technology.

OLIVEIRA GC, VIEIRA WL, BERTOLLI SC AND PACHECO AC. 2016. Photosynthetic behavior, growth and essential oil production of Melissa officinalis L. cultivated under colored shade nets. Chil J Agric Res 76: 123-128.

OLIVEIRA MI, CASTRO EM, COSTA LCB AND OLIVEIRA C. 2009. Características biométricas, anatômicas e fisiológicas de Artemisia vulgaris L. cultivada sob telas coloridas. Rev Bras P1 Med 11: 56-62.

PINTO JEBP, CARDOSO JCW, CASTRO EMD, BERTOLUCCI SKV, DE MELO LA AND DOUSSEAU S. 2007. Aspectos morfofisiológicos e conteúdo de óleo essencial de plantas de alfazema-do-Brasil em função de níveis de sombreamento. Hortic Bras 25: 210-214.

R DEVELOPMENT CORE TEAM. 2012. R: A language and environment for statistical computing. Austria: $\mathrm{R}$ Foundation for Statistical Computing.

RAM MD, RAM S, SINGH S, NAQVI AA AND KUMAR S. 1999. Studies on intercropping of patchouli (Pogostemon patchouli) with papaya (Carica papaya). J Med Aromat Plants 21: 358-360.

RUSYDI A, TALIP N, LATIP J, RAHMAN RAAND SHARIF I. 2013. Morphology of trichomes in Pogostemon cablin Benth. (Lamiaceae). Aust J Crop Sci 7: 744-749.

SHA VALLI KHAN PS, KOZAI T, NGUYEN QT, KUBOTA C AND DHAWAN V. 2002. Growth and net photosynthetic rates of Eucalyptus tereticornis Smith under photomixotrophic and various photoautotrophic 
micropropagation conditions. Plant Cell Tissue Organ Cult 71: 141-146.

SHAHAK Y, GUSSAKOVSKY EE, GAL E AND GANELEVIN R. 2004. Colornets: crop protection and light-quality manipulation in one technology. Acta Hortic 659: 143-151.

SHIMAZAKI KI, DOI M, ASSMANN SM AND KINOSHITA T. 2007. Light regulation of stomatal movement. Annu Rev Plant Biol 58: 219-247.

SILVA LM, ALQUINI Y AND CAVALLET VJ. 2005. Interrelações entre a anatomia vegetal e a produção vegetal. Acta Bot Brasilica 19: 183-194.

SILVA ST, BERTOLUCCI SKV, DA CUNHA SHB, LAZZARINI LES, TAVARES MC AND PINTO JEBP. 2017. Effect of light and natural ventilation systems on the growth parameters and carvacrol content in the in vitro cultures of Plectranthus amboinicus (Lour.) Spreng. Plant Cell Tissue Organ Cult 129: 501-510.

SONWA MM. 2000. Isolation and structure elucidation of essential oil constituents: comparative study of the oils of Cyperus alopecuroides, Cyperus papyrus, and Cyperus rotundus. Hamburg: University of Hamburg.

SOUZA GS, PINTO JEBP, RESENDE MG, BERTOLUCCI SKV, SOARES ÂM AND CASTRO EM. 2011. Crescimento, teor de óleo essencial e conteúdo de cumarina de plantas jovens de gauco (Mikania glomerata Sprengel) cultivadas sob malhas coloridas. Rev Biotemas 24: 1-11.

SUKARDI, SOEPARMAN S, ARGO BD AND IRAWAN YS. 2017. Optimization of patchouli oil (Pogostemon cablin, Benth) with steam distillation assisted by pulsed electric field via response surface methodology. J Eng Sci Technol 12: $2106-2119$.

SWAMY M AND SINNIAH U. 2015. A comprehensive review on the phytochemical constituents and pharmacological activities of Pogostemon cablin Benth.: an aromatic medicinal plant of industrial importance. Molecules 20(5): 8521-8547.

TAIZ L AND ZEIGER E. 2009. Fisiologia vegetal, 4ª ed., Porto Alegre: Artmed, $90 \mathrm{p}$.

VAN DEN DOOL H AND KRATZ PD. 1963. A generalization of the retention index system including linear temperature programmed gas-liquid partition chromatography. J Chromatogr A 11: 463-471.

VON ARNIM A AND DENG XW. 1996. Light Control of seedling development. Annu Rev Plant Physiol and Plant Mol Biol 47: 215-243.

YAHYA A AND YUNUS RM. 2013. Influence of sample preparation and extraction time on chemical composition of steam distillation derived patchouli oil. Procedia Eng 53: 1-6. 